\title{
Deep Gray Matter
}

National Cancer Institute

\section{Source}

National Cancer Institute. Deep Gray Matter. NCI Thesaurus. Code C158080.

The gray matter that includes the basal ganglia and/or thalamus. 